\title{
DNA Damage, Mutagenesis and Cancer
}

\author{
Ashis K. Basu \\ Department of Chemistry, University of Connecticut, Storrs, CT 06269-3060, USA; ashis.basu@uconn.edu; \\ Tel.: +1-860-486-3965 \\ Received: 29 January 2018; Accepted: 20 March 2018; Published: 23 March 2018

\begin{abstract}
A large number of chemicals and several physical agents, such as UV light and $\gamma$-radiation, have been associated with the etiology of human cancer. Generation of DNA damage (also known as DNA adducts or lesions) induced by these agents is an important first step in the process of carcinogenesis. Evolutionary processes gave rise to DNA repair tools that are efficient in repairing damaged DNA; yet replication of damaged DNA may take place prior to repair, particularly when they are induced at a high frequency. Damaged DNA replication may lead to gene mutations, which in turn may give rise to altered proteins. Mutations in an oncogene, a tumor-suppressor gene, or a gene that controls the cell cycle can generate a clonal cell population with a distinct advantage in proliferation. Many such events, broadly divided into the stages of initiation, promotion, and progression, which may occur over a long period of time and transpire in the context of chronic exposure to carcinogens, can lead to the induction of human cancer. This is exemplified in the long-term use of tobacco being responsible for an increased risk of lung cancer. This mini-review attempts to summarize this wide area that centers on DNA damage as it relates to the development of human cancer.
\end{abstract}

Keywords: carcinogenesis; carcinogen; mutagen; metabolism; DNA adduct; tumor; chronic exposure; somatic mutation

\section{History}

In 1761, after use of tobacco for recreation became popular in London, physician John Hill wrote a book entitled "Cautions Against the Immoderate Use of Snuff". Hill's observations that tobacco snuff can cause "polypus" (i.e., small vascular growth on the surface of a mucous membrane) led to epidemiology studies nearly 200 years later in 1950s and 1960s, which convincingly established that tobacco smoking causes lung cancer. A few years after Hill's book was available, in 1775, Sir Percivall Pott of Saint Bartholomew's Hospital in London published a groundbreaking essay showing that exposure to soot leads to high incidence of scrotal cancer in young men worked as chimney sweeps, which he named the chimney-sweepers' cancer [1]. This was the first occupational link to cancer. This also was the first association to materials such as soot (a complex mixture of chemicals) to the etiology of cancer. He further hypothesized that the scrotum of young men working as chimney sweeps were particularly susceptible for scrotal cancer later in life, due to their chronic exposure to soot. Sir Percival Pott's remarkable insight notwithstanding, it took nearly seventy years to pass a law in the UK to protect children from working as chimney sweeps. Perhaps more remarkably, almost 150 years passed when additional studies were attempted on chemical carcinogens, even though an association between certain chemicals and cancer has been reported from time to time. For instance, in 1895 Rehn described the first cases of bladder cancer in German fuchsin dye manufacturing workers.

An important advance was made in the early 20th century, when Yamagiwa and Ichikawa, two Japanese investigators, developed the first animal assay for carcinogens $[2,3]$. They repeatedly applied the test compound(s), such as coal tar, on the skin of rabbit ears. Tumors were developed in the experimental animals after a few weeks. Later, rats and mice were found to be better suited for 
this type of assays [4]. Even though these assays are slow, arduous, and expensive, it continues to be the experimental approach to determine if a compound or a mixture of compounds cause tumorigenesis in mammals. In the 1930s Cook, Kennaway and coworkers were able to isolate and identify benzo $[a]$ pyrene $(\mathrm{B}[a] \mathrm{P})$, a polycyclic aromatic hydrocarbon $(\mathrm{PAH})$, as a potent carcinogen present in soot and coal tar [5,6]. Subsequently, other PAHs were isolated from coal tar and synthetic methods to prepare them were also developed. Over the years, many other groups of compounds and mixtures have been recognized as human carcinogens. Specifically in the 1930s and 1940s, reports of bladder cancers from DuPont and other American dye manufacturers were documented $[7,8]$. In addition to PAHs (in soot and coal tar) and aromatic amines (present in dyes) [9], numerous other classes of compounds including nitroaromatics [10], asbestos [11], chromium, nickel, and arsenic compounds [12], vinyl chloride [13], aflatoxins [14], diesel exhaust [15], and most notably, tobacco smoke [16], were found to cause cancer. Physical agents like UV light [17] and gamma radiation [18,19] also turned out to be carcinogenic.

\section{Metabolic Activation and DNA Damage}

In 1950, Boyland proposed that arene oxides are the major metabolites of PAHs that give rise to the phenols, dihydrodiols, and other oxidation products [20]. But the mechanism of the in vivo effects of these carcinogens was little understood until DNA was shown to be the genetic material responsible for coding for all biological processes [21], and the structure of DNA was elucidated by Watson and Crick [22] on the basis of Rosalind Franklin's unpublished crystal structure of DNA. It became gradually clear that many of the carcinogenic chemicals are metabolically activated to electrophilic species that bind to DNA or cause DNA damage [23-25]. Extensive investigations were performed to establish how each carcinogenic agent, either directly or following metabolic changes in their structures, damage DNA or form DNA adducts. As for example, $\mathrm{B}[a] \mathrm{P}$ is converted to $7 S, 8 R-\mathrm{B}[a] \mathrm{P}$ oxide by cytochrome P-450 (CYP) 1A1/1B1, which is hydrolyzed by microsomal epoxide hydrolase to form the $(-)-7 R, 8 R$-dihydroxydihydro- $\mathrm{B}[a] \mathrm{P}[26,27]$ (Figure 1 ). This trans dihydrodiol is then oxidized again by the same CYP 1A1/1B1 enzymes to form predominantly (+)-anti-B[a]P-7,8-dihydrodiol-9,10-epoxide, the most mutagenic and tumorigenic metabolite of $\mathrm{B}[a] \mathrm{P}$. The major adduct formed by this $\mathrm{B}[a] \mathrm{P}$ metabolite is the (+)-trans-anti-B[a]PDE (Figure 1).

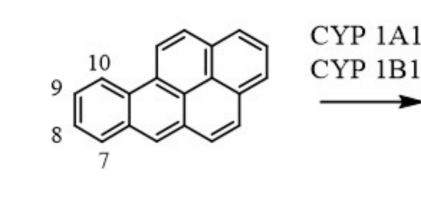

Benzo $[a]$ pyrene $(\mathrm{B}[a] \mathrm{P})$

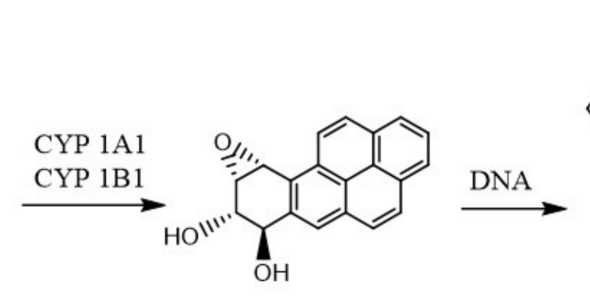

(+)-anti- B $[a] \mathrm{P}-7,8$-dihydrodiol $-9,10$-epoxide

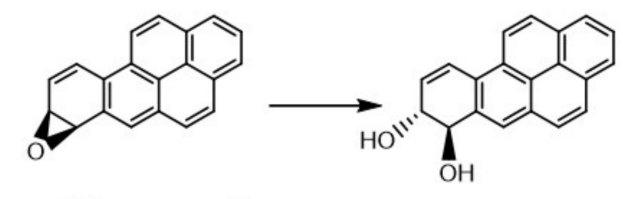

$\mathrm{B}[a] \mathrm{P}-7,8$-epoxide

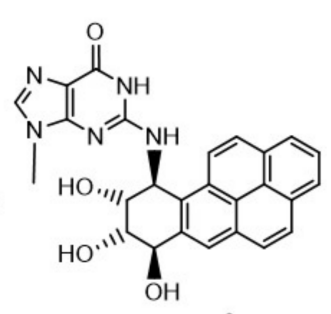

(+)-trans-anti-dG- $N^{2}$-BPDE

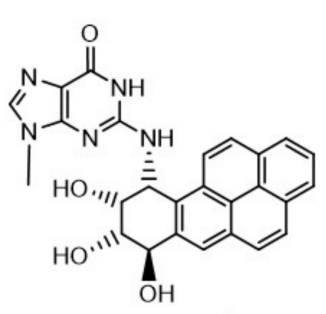

(+)-cis-anti-dG- $N^{2}-\mathrm{BPDE}$

Figure 1. Microsomal metabolic activation of benzo[a]pyrene to its most reactive (+)-anti-B $[a] \mathrm{P}-7,8-$ dihydrodiol-9,10-epoxide, which reacts with DNA to form the dG adducts.

UV light, on the other hand, is an example of a direct acting agent that damages DNA [28-31], although it also damages DNA indirectly via reactive oxygen species. UV light is considered to be responsible for most skin cancers. UVB (280-320 nm) and UVC (240-280 nm) irradiation form cis-syn 
cyclobutane dimer and pyrimidine(6-4)pyrimidone photoproducts (Figure 2) as the main products in duplex DNA. The chemically stable (6-4) photoproduct may undergo conversion to its Dewar isomer by UVA or UVB light.<smiles>CN1C(=O)NC(=O)[C@]2(C)[C@H]1[C@]1(C)C(=O)NC(=O)N(C)[C@@H]12</smiles>

cis-syn thymine dimer<smiles>Cc1cn(C)c(=O)nc1[C@@]1(O)N(C)C(=O)NC(=O)[C@@]1(C)O</smiles>

$(6-4)$
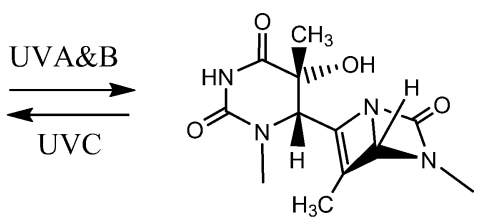

Dewar

Figure 2. The chemical structures of UV light induced cis-syn thymine dimer, pyrimidine(6-4)pyrimidone and Dewar photoproducts formed by two adjacent thymines.

Similar to $\mathrm{B}[a] \mathrm{P}$, metabolism and DNA binding by a large number of chemical carcinogens have been reported. Figure 3 shows the chemical structures of a few of these carcinogenic compounds, which include PAHs, nitroaromatic compounds, aromatic amines, natural products, industrial chemicals, and a chemotherapeutic agent that also induces secondary tumor.

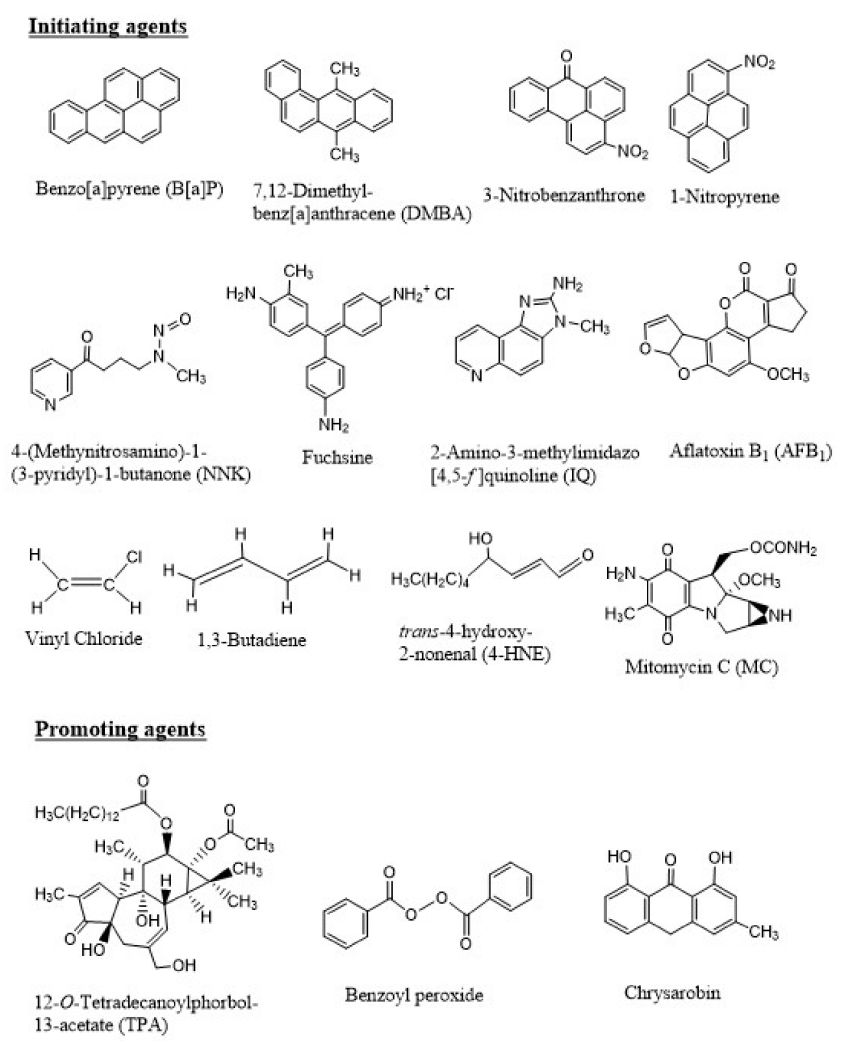

Figure 3. Chemical structures of a few initiating and promoting agents. The initiating agents shown here include polycyclic aromatic hydrocarbons (PAHs) (B[a]P and DMBA, present in soot, coal tar, and many environmental mixtures), nitroaromatic compounds (3-nitrobenzanthrone and 1-nitropyrene, present in diesel exhaust), tobacco-specific nitrosamine (NNK, present in tobacco smoke), an amine salt and a magenta dye (fuchsine), aromatic amine (IQ, formed during cooking of meat), a naturally occurring molecule produced by Aspergillus flavus ( $\mathrm{AFB}_{1}$, a food contaminant), industrial chemicals (vinyl chloride and 1,3-butadiene to make the polymer PVC and synthetic rubber, respectively), lipid peroxidation product (4-HNE, produced in cells and tissues of living organisms or in foods during processing or storage), and a chemotherapeutic agent (MC, a toxic drug used to treat upper gastrointestinal cancers). The promoting agents include the phorbol ester (TPA), benzoyl peroxide, and chrysarobin. 


\section{Multi-Step Process of Cancer}

As early as in the 1940s, it became apparent that the process of carcinogenesis involves at least two distinct steps. In 1944, Mottram showed that a single application of a carcinogen, such as B[a]P, followed by multiple applications of an "irritant", such as croton oil, induce tumors in animals [32]. Berenblum and Shuvik followed up this study with application of either $\mathrm{B}[a] \mathrm{P}$ or 7,12-dimethylbenz[a]anthracene (DMBA) and croton oil, and demonstrated that croton oil, a non-carcinogen, had no effect alone, but when applied after even a single dose of either $\mathrm{B}[a] \mathrm{P}$ or DMBA on mouse skin, tumors were developed [32]. These results led to the hypothesis of "initiation" (result of application of the carcinogen like $\mathrm{B}[a] \mathrm{P}$ ) followed by "promotion" (caused by croton oil). Later, croton oil was shown to contain the phorbol ester, 12-O-tetradecanoylphorbol-13-acetate (TPA), as the active ingredient that is responsible for the promotion phase in carcinogenesis [33]. Additional tumor promoters, including benzoyl peroxide, okadaic acid, chrysarobin, have been identified (Figure 3).

There are several fundamental differences between these two stages (and the agents that trigger these processes) [34-37]. An initiating agent is also a "complete carcinogen", since either repeated exposure in small dosage or a single large exposure to such agents lead to carcinogenesis, whereas a promoting agent is not carcinogenic alone. The effect of an initiating agent, in addition, is irreversible and additive, in contrast to the reversible action of a promoting agent at the early stages. The initiating agents furthermore become electrophilic after metabolic activation, and bind to cellular macromolecules such as DNA, while there is no evidence of covalent binding by the promoting agents. The initiating agents are mutagenic and, as a result, quite a few short-term assays have been developed [38-41], whereas the promoting agents are not mutagenic. Experiments in rodents on the two-stage model, however, showed that mainly benign tumors were developed by tumor promoters [42]. It became gradually accepted that carcinogenesis involves multi-stages, which include initiation, promotion, and malignant progression, when benign neoplasms become malignant and invasive lesions [43] (Figure 4).

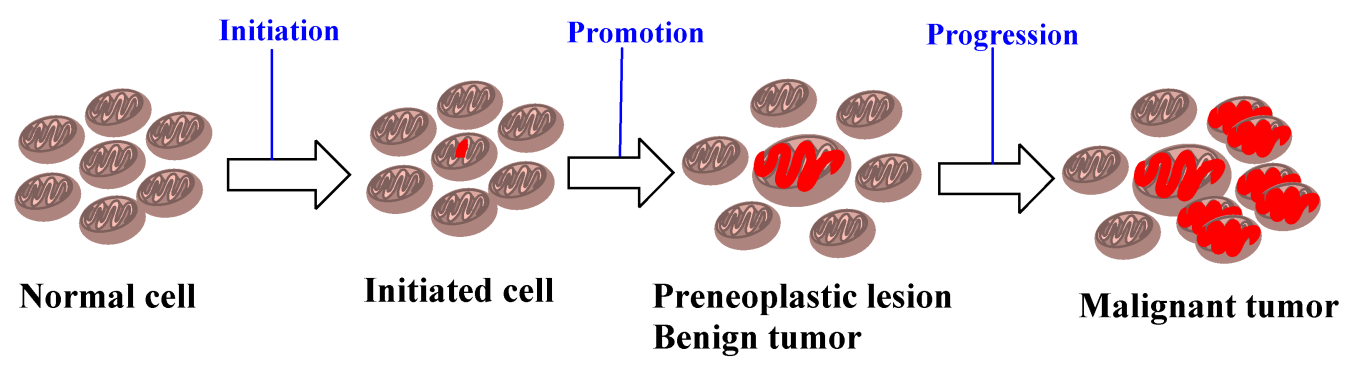

Figure 4. A brief depiction of initiation, promotion, and progression in the process of carcinogenesis.

Discovery of oncogenes and tumor suppressor genes added to the concept that carcinogenesis is a multi-step process [43,44]. Notably, continuous oxidative stress and chronic inflammation sustain each other, leading to neoplasm, and promote tumor progression. Inflammation has been associated with the development of cancer, and inflammatory mediators, like cytokines, chemokines, and eicosanoids, have been shown to stimulate the proliferation of both untransformed and tumor cells [45]. Certain initiating agents, such as UV light and tobacco smoke also exhibit strong tumor promoting activity.

Most of our understanding of tumor promotion comes from experiments performed on mouse skin [46]. The promotion stage in carcinogenesis induces a number of epigenetic changes, including proliferation of epidermal cells and activation of ornithine decarboxylase that leads to synthesis of polyamines [47-49]. Overall, the promotion stage is characterized by hyperplasia, that leads the initiated cells to form papillomas. Strong tumor promoters, such as the phorbol esters, activate membrane receptors like protein kinase C [50]. Activation of protein kinase $C$ phosphorylation of critical proteins is considered an important event in skin tumor promotion. Several other tumor promotors, including benzoyl peroxide, appear to involve free-radical mechanisms, which indirectly lead to phosphorylation of certain proteins [51]. Tumor promotion is also characterized by clastogenic 
effect and genetic instability, resulting in chromosomal alterations. Consequently, tumor promotion includes a series of complicated epigenetic steps leading to formation of papillomas. Tumor promotion can also be induced by tumor necrosis factor- $\alpha$ (TNF- $\alpha$ ) and TNF- $\alpha$-inducing protein (Tip $\alpha$ ) of Helicobacter pylori stimulates progression phase [52]. Recent studies on human cancer development includes upregulation of TNF- $\alpha$ and activation of NF- $\mathrm{kB}$, an important transcription factor [52].

\section{DNA Damage and DNA Repair}

DNA damage occurs continuously in all organisms via a number of endogenous and exogenous factors, and it seems to play a central role in many biological processes, ultimately leading to cancer (Figure 5). Hence, robust DNA repair systems, which repair this damage, have evolved to maintain genomic integrity. The importance of DNA repair was underscored by conferring the Nobel Prize in Chemistry in 2015 to Tomas Lindahl, Paul Modrich, and Aziz Sancar for mapping, at a molecular level, how cells repair damaged DNA and protect the genetic information. There are a number excellent reviews on DNA repair, which summarize this rapidly evolving field [53-57].

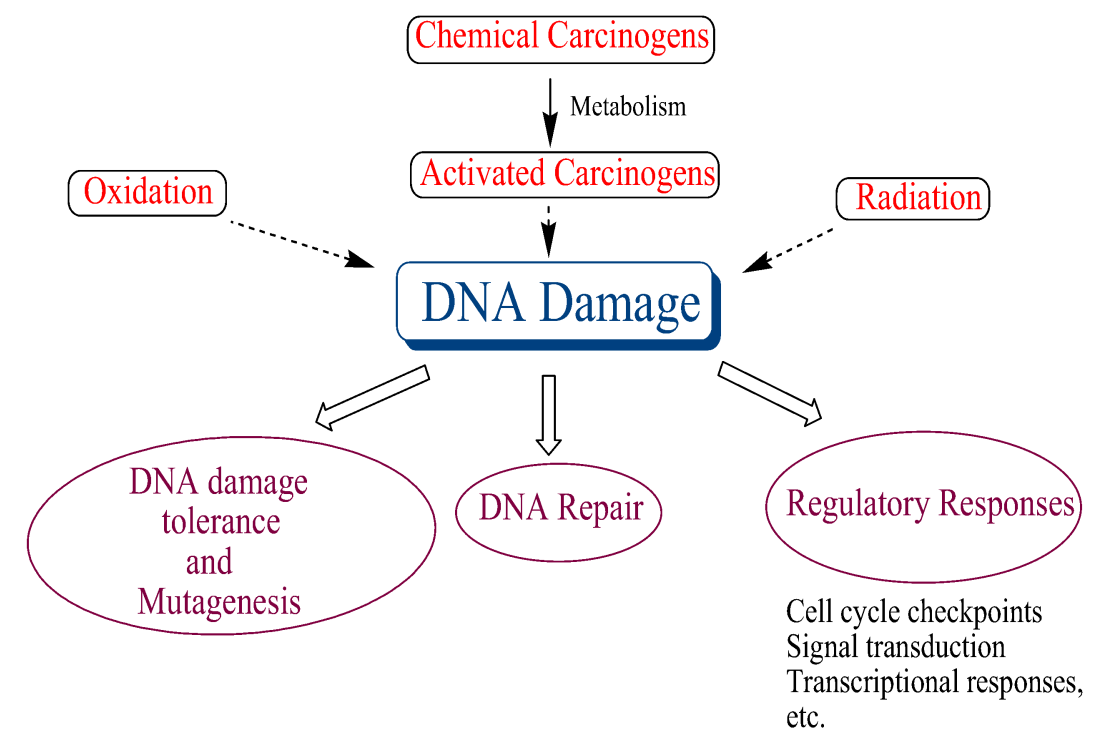

Figure 5. DNA damage plays a central role in many biological processes linked to cancer.

DNA replication occurs during the $S$ (synthetic) phase of cell cycle, which is preceded by the G1 (Gap 1) phase. The nuclear division occurs in the M (mitosis) phase, which takes place after the G2 phase. The differentiated cells at the G0 phase do not proliferate, whereas the G1, S, and G2 phases of a proliferating cell constitute the time lapse between two consecutive mitoses. The progression of a cell during cell cycle is regulated by cyclin dependent kinase in order to avoid the initiation of a cell cycle before the preceding one is completed. DNA damage interferes with the cell cycle, and therefore, there are checkpoint proteins that delay cell cycle progression providing the necessary time for DNA repair. If the DNA damage exceeds the capability of repair, pathways to trigger cell death are activated by apoptosis. The checkpoint pathways accordingly play an integral role in DNA damage response, and dysfunction of these pathways are important for the pathogenesis of malignant cells [58].

\section{Relationship between DNA Adducts and Tumor Incidence}

Carcinogens and mutagens usually generate multiple DNA adducts, and it was shown that certain adducts are biologically more relevant than others. Many diseases in humans are the result of specific genetic mutations. Therefore, DNA adducts or lesions that lead to mutations became the focus of many studies. As for example, the predominant mutation induced by most methylating and ethylating 
agents are $\mathrm{G}: \mathrm{C} \rightarrow \mathrm{A}: \mathrm{T}$ transitions induced by $\mathrm{O}^{6}$-alkylguanine, even though the major adduct is formed at the N7-position of guanine [59].

Characterization of a quantitative relationship between DNA adduct levels and tumor incidences in rats and mice was attempted by Ottender and Lutz [60]. Of the 27 different chemicals investigated, the range of carcinogenic potency of structurally different DNA adducts is typically within 2 orders of magnitude. In the rat, for instance, 53 adducts per $10^{8}$ nucleotides for the aflatoxin B1 to 2082 adducts per $10^{8}$ nucleotides for dimethylnitrosamine relate to the normalized $50 \%$ level of liver tumor incidences, suggesting that the aflatoxin-DNA adducts are 40 times more potent than the adducts formed by dimethylnitrosamine for inducing hepatocellular carcinoma.

\section{Damaged DNA Replication}

DNA replication causes mutations and DNA damage, or DNA adducts increases the rate of error-prone replication [61]. However, each DNA damage or adduct has a unique mutational signature, which is directly related to the identity of the DNA polymerase that bypass it and the mechanism of its nucleotide insertion and extension [61].

A human cell contains at least 17 different DNA polymerases. The DNA polymerases belong to seven families (A, B, C, D, X, Y, and RT) [62,63], of which the C family enzymes were only found in prokaryotes. In eukaryotes, the B-family enzymes pol $\varepsilon$ and pol $\delta$ carry out a large fraction of nuclear DNA replication, whereas pol $\alpha$ of the same family performs initiation and priming. These three polymerases are essential for DNA replication in eukaryotes. In the current model of DNA replication, pol $\varepsilon$ carries out majority of leading strand DNA replication of the undamaged genome, whereas pol $\delta$ primarily replicates the lagging strand. But this model has recently been challenged, and data supporting involvement of pol $\delta$ in both leading and lagging strand replication have been presented [64-66]. It is noteworthy that these important DNA polymerases are inefficient in bypassing most bulky or distorting DNA damages, such as the ones induced by PAHs and UV light.

The discovery of translesion synthesis (TLS) DNA polymerases in the 1990s and the study of their catalytic and non-catalytic roles in damaged DNA replication provided much of our current understanding of DNA adduct or lesion bypass [63]. Lesion bypass is carried out primarily by the Y-family polymerases. But X- and B-family polymerases are also involved in many cases.

TLS of various types of DNA damage have been conducted by genetic studies in repair and replication competent cells, by in vitro experiments using purified DNA polymerases and accessory proteins, and by structural and computational studies. The mechanistic information gathered from these studies is critical to understand the mechanism of mutagenesis, the underlying process for the development of cancer. These fundamental studies are now allowing therapeutic application, as inhibiting the activity of some of the TLS polymerases may enhance the effect of an antitumor agent.

\section{Epidemiology}

At the international cancer congress held in Tokyo in 1966, Sir Alexander Haddow, the President of international union against cancer, pronounced: "We are impressed by the probability that a much higher proportion of human cancer than we had ever recently suspected-perhaps amounting to as much as 80 percent-may be due to environmental causes" [67]. These remarks from an eminent cancer researcher are significant, because it suggests that most human cancers are preventable. The most common preventable risk factors for cancer are tobacco smoking, diet (low in fruits and vegetable and high in fatty foods, red meats, etc.), obesity, and alcohol [68-73]. Cancer rate also increases with age, but age-related cancer patterns are fairly complex.

Epidemiology showing the definitive link between tobacco smoke and cancer was a noteworthy achievement in the United States, and the Surgeon General's Report in 1964 had a significant positive effect on public health in this country. The smoking prevalence in males decreased by about $60 \%$, while prevalence in females diminished by about 50\% [74]. As a result, lung cancer mortality and other 
tobacco-related diseases continue to decrease. These facts reiterate the importance of tobacco control in prevention of cancer and other diseases [16,75-77].

Epidemiology of skin cancer has also been enlightening [78]. One in every three cancers diagnosed is a skin cancer, and one in every five Americans will develop skin cancer in their lifetime. Melanoma and nonmelanoma skin cancer (NMSC) are the most common types of cancer mainly in the white populations. Both types of tumors show an increasing incidence rate worldwide, but a stable or decreasing mortality rate, presumably due to earlier diagnosis and better treatments. NMSC is the most common cancer in fair-skinned individuals, which causes significant morbidity. The rising incidence rates of NMSC are believed to be triggered by a combination of increased exposure to direct UV rays or UV in sunlight, increased longevity, ozone depletion, genetics, and in a limited number of cases, immune suppression.

\section{Mutation and Cancer}

Several types of cancers are the result of at least a few mutations in critical genes $[79,80]$. The somatic mutation theory (SMT) of cancer, the most prevalent model, proposes that cancer is caused by mutation(s) in the body cells (as opposed to germ cells), especially nonlethal mutations associated with increased proliferation of the mutant cells. The SMT hypothesis originated from Theodore Boveri's postulate in 1914 that a combination of chromosomal defects could result in cancer [81]. After Watson and Crick's discovery of the structure of DNA that also implied that DNA contains the genetic information, in 1953, Carl O. Nordling proposed that several mutated genes may lead to cancer [82]. Ashley suggested that cancer may occur as a result of three to seven mutations [83]. Alfred Knudson modified Ashley's proposal, based on his observations of a number of retinoblastoma cases, proposing that cancer is the result of accumulated mutations to a cell's DNA, which could be as little as two hits [84]. The two-hit model proposes that dominantly inherited predisposition to cancer requires a germline mutation, while tumorigenesis necessitates a second somatic mutation. For colorectal carcinoma, Fearon and Vogelstein suggested that four to five gene mutations are necessary for the development of malignant tumor, and the accumulation of the mutations, rather than their specific order, is the critical determinant of tumorigenesis [85]. More recently, these mutations have been referred to as "driver" mutations conferring growth advantage to the cells [79]. In humans, more than 350 mutated genes that are implicated in the development of cancer have been identified. A large-scale sequencing study has shown that most somatic mutations in cancer cells are "passengers" that do not cause tumorigenesis, whereas 120 of the 518 genes screened ( 23\%) carry a "driver" mutation, which can function as cancer genes. Similar conclusions have been reached in other studies $[79,86]$. The basic premise of SMT, however, has been challenged from time to time [87].

Genes that contribute to cancer include oncogenes and tumor suppressor genes. Oncogenes change a normal healthy cell into a cancerous cell. Examples include the ras family of genes and HER2. The ras genes produce proteins engaged in cell communication pathways, cell growth, and cell death, whereas HER2 makes specialized proteins controlling cell growth, and spread notably in breast and ovarian cancer cells. DNA adduct-induced mutations in the ras gene, at the activating codons $12,13,59$, and 61 , are considered to be of note. Aflatoxin $B_{1}\left(\mathrm{AFB}_{1}\right)$ causes G.C $\rightarrow A \cdot T$ or $G \cdot C \rightarrow T \cdot A$ substitutions at codon 12 in experimental animals [88]. Analyses of lung tumors in $\mathrm{A} / \mathrm{J}$ mice by the tobacco-specific nitrosamine 4-(methylnitrosamino)-1-(3-pyridyl)-1-butanone (NNK) and related compounds showed high frequency of $\mathrm{G} \rightarrow$ A mutations (GGT to GAT) in codon 12 [89]. By contrast, tumor suppressor genes protect a cell from becoming cancerous. The tumor suppressor proteins control cell growth by monitoring cell division, repairing base mismatches in DNA, and controlling cell death (apoptosis). Examples of tumor suppressor genes include $p 53, B R C A 1$, and BRCA2. More than $50 \%$ of human cancers are characterized by mutations in the $p 53$ gene, and most $p 53$ gene mutations are not hereditary. Germline mutations in BRCA1 or BRCA2 gene increases a woman's risk of hereditary breast and ovarian cancer. A convincing relationship between a chemical and $p 53$ mutation in human cancer has been shown in geographical areas where $\mathrm{AFB}_{1}$-derived liver cancers 
accompanied unusually high frequency of G.C $\rightarrow$ T.A mutations at the third base of codon 249 of the p53 gene [90]. Also, a human liver cell line following exposure to $\mathrm{AFB}_{1}$ showed the same mutation at the third base of $p 53$ codon 249 [91]. Likewise, for lung cancer cases of smokers, $\sim 40 \%$ of the mutations involved $\mathrm{G} \rightarrow \mathrm{T}$ transversions, and more than $90 \%$ of them are on a guanine on the non-transcribed strand [90]. Major hotspots are observed at codons 157, 248, and 273. Even though codon 157 is unique to lung cancer, the other two are hotspots for mutations in many other cancers, usually detected as transitions at these CpG sequences, whereas in lung cancers, $G \rightarrow T$ transversions are the most common mutations [92]. Pfeifer and colleagues have claimed that sequence specificity of $G \rightarrow T$ transversions in lung tumors is consistent with a direct mutagenic action of PAH compounds, such as $\mathrm{B}[a] \mathrm{P}$ present in cigarette smoke [93]. In addition to the cancers induced by exogenous agents, few hereditary cancers, which include retinoblastoma and Li-Fraumeni syndrome, involve germline mutations in tumor suppressor genes [94,95].

Human tumors are largely heterogeneous. Loeb and coworkers suggest that this heterogeneity results from a mutator phenotype. They hypothesized that increased mutation rates are essential to account for the large number of mutations observed in cancer cells [96,97]. Consequently, an initial mutator mutation triggers additional mutations, including mutations in genes that maintain genetic stability, starting a cascade of mutations throughout the genome. Several types of cancers exhibit mutator phenotype resulting from mutations at loci responsible for DNA mismatch repair [98]. It was also proposed that $p 53$ mutations might give rise to mutator phenotype, because p53 is a gatekeeper of DNA damage responses [99]. However, others believe that a mutator phenotype is not necessary for tumor initiation and progression, in spite of the fact that some tumors may acquire it during tumorigenesis [100].

In one of the most highly cited articles, entitled "Hallmarks of Cancer", in the year 2000, Hanahan and Weinberg suggested that the complexity of cancer can be summarized in six hallmarks that enable normal cells to turn tumorigenic and ultimately malignant [101]. These hallmarks are as follows: (1) self-sufficiency in growth signals, implying the ability of tumor cells to grow in the absence of the signals that allow them to grow, (2) insensitivity to anti-growth signals, i.e., they resist the signals to stop growth, (3) evading apoptosis, i.e., they resist their programmed death, (4) limitless replicative potential, so that they can multiply indefinitely, (5) sustained angiogenesis, i.e., they stimulate the blood vessel growth in order to supply nutrients to the tumor cells, and (6) tissue invasion and metastases, i.e., they invade surrounding tissues and spread to distant sites. However, Lazebnik pointed out that hallmarks 1-5 are also the characteristics of benign tumors [102]. In an update of the Hallmark paper, in 2011, Hanahan and Weinberg proposed four additional hallmarks: (1) abnormal metabolic pathways, (2) evading the immune system, (3) genome instability, and (4) inflammation [103]. In principle, the cancer phenotypes proposed as hallmarks are based on the SMT and its cell-centered variants. Others, though, argued that cancer is a tissue-level disease and cataloguing such cellular-level hallmarks are misleading [104].

\section{Conclusions}

A detailed understanding of multi-stage carcinogenesis is important for both the treatment and prevention of cancer. This area of research, for the last fifty years, has provided us a great deal of mechanistic information on initiation, promotion, and progression, the three main steps leading to cancer. Consequently, many types of cancer deaths have been reduced in the USA over the last two decades, to an overall reduction of $23 \%$, and more than 1.7 million cancer deaths were averted [105]. In spite of this progress, cancer is still the leading cause of death for much of the US population. Likewise, there has been significant reduction in several European countries. Unfortunately, progress has been limited in many other countries, due to the lack of adequate cancer diagnosis and limited medical treatment capabilities $[106,107]$. In fact, more than $60 \%$ of the world's new cancer cases take place in Africa, Asia, and Central and South America, and 70\% of the world's cancer deaths occur in these continents. Therefore, it is imperative to continue further studies on the mechanism 
of carcinogenesis with the objective of prevention, treatment, as well as developing new strategies to combat this deadly disease.

Acknowledgments: Research in the AKB laboratory has been supported by the NIH (NIEHS grants ES09127, ES027558, and ES023350).

Conflicts of Interest: The author declares no conflict of interest.

\section{Abbreviations}

PAH polycyclic aromatic hydrocarbon

$\mathrm{B}[a] \mathrm{P}$ benzo[a]pyrene

CYP cytochrome P-450

UV ultraviolet

TPA 12-O-tetradecanoylphorbol-13-acetate

TNF- $\alpha$ tumor necrosis factor- $\alpha$

TLS translesion synthesis

NMSC nonmelanoma skin cancer

SMT somatic mutation theory

\section{References}

1. Brown, J.R.; Thornton, J.L. Percivall Pott (1714-1788) and chimney sweepers' cancer of the scrotum. Br. J. Ind. Med. 1957, 14, 68-70. [CrossRef] [PubMed]

2. Yamagiwa, K.; Ichikawa, K.J. Experimental Study of the Pathogenesis of Carcinoma. Cancer Res. 1918, 3, 1-29. [CrossRef]

3. Yamagiwa, K.; Ichikawa, K. Experimental study of the pathogenesis of carcinoma. CA Cancer J. Clin. 1977, 27, 174-181. [CrossRef] [PubMed]

4. Tsutsui, H. Uber das kustlich erzeugte cancroid bei der maus. Gann 1918, 12, 17-21.

5. Cook, J.W.; Hieger, I.; Kennaway, E.L.; Mayneord, W.V. The production of cancer by pure hydrocarbons. R. Soc. Proc. 1932, 111, 455-484. [CrossRef]

6. Cook, J.W.; Hewett, C.L.; Hieger, I. The isolation of a cancer-producing hydrocarbon from coal tar. Parts I, II, and III. J. Chem. Soc. 1933, 0, 395-405. [CrossRef]

7. Stern, F.B.; Murthy, L.I.; Beaumont, J.J.; Schulte, P.A.; Halperin, W.E. Notification and risk assessment for bladder cancer of a cohort exposed to aromatic amines. III. Mortality among workers exposed to aromatic amines in the last beta-naphthylamine manufacturing facility in the United States. J. Occup. Med. 1985, 27, 495-500. [PubMed]

8. Michaels, D. When Science Isn't Enough: Wilhelm Hueper, Robert A. M. Case, and the Limits of Scientific Evidence in Preventing Occupational Bladder Cancer. Int. J. Occup. Environ. Health 1995, 1, 278-288. [CrossRef] [PubMed]

9. Clayson, D.B. Specific aromatic amines as occupational bladder carcinogens. Natl. Cancer Inst. Monogr. 1981, 58, 15-19.

10. Purohit, V.; Basu, A.K. Mutagenicity of nitroaromatic compounds. Chem. Res. Toxicol. 2000, 13, 673-692. [CrossRef] [PubMed]

11. Nicholson, W.J. The carcinogenicity of chrysotile asbestos-A review. Ind. Health 2001, 39, 57-64. [CrossRef] [PubMed]

12. Hayes, R.B. The carcinogenicity of metals in humans. Cancer Causes Control 1997, 8, 371-385. [CrossRef] [PubMed]

13. Brady, J.; Liberatore, F.; Harper, P.; Greenwald, P.; Burnett, W.; Davies, J.N.; Bishop, M.; Polan, A.; Vianna, N. Angiosarcoma of the liver: An epidemiologic survey. J. Natl. Cancer Inst. 1977, 59, 1383-1385. [CrossRef] [PubMed]

14. Wogan, G.N. Aflatoxin as a human carcinogen. Hepatology 1999, 30, 573-575. [CrossRef] [PubMed]

15. Taxell, P.; Santonen, T. Diesel Engine Exhaust: Basis for Occupational Exposure Limit Value. Toxicol. Sci. 2017, 158, 243-251. [CrossRef] [PubMed] 
16. Hecht, S.S. Tobacco smoke carcinogens and lung cancer. J. Natl. Cancer Inst. 1999, 91, 1194-1210. [CrossRef] [PubMed]

17. Soehnge, H.; Ouhtit, A.; Ananthaswamy, O.N. Mechanisms of induction of skin cancer by UV radiation. Front. Biosci. 1997, 2, d538-d551. [PubMed]

18. Robock, A.; Toon, O.B. Local nuclear war, global suffering. Sci. Am. 2010, 302, 74-81. [CrossRef] [PubMed]

19. IARC. Ionizing Radiation: Part 1: X-and Gamma (y)-Radiation, and Neutrons (IARC Monographs on the Evaluation of the Carcinogenic Risks to Humans) (Pt. 1), 1st ed.; IARC: Lyon, France, 2000.

20. Boyland, E.; Wolf, G. Metabolism of polycyclic compounds. 6. Conversion of phenanthrene into dihydroxydihydrophenanthrenes. Biochem. J. 1950, 47, 64-69. [CrossRef] [PubMed]

21. Avery, O.T.; Macleod, C.M.; McCarty, M. Studies on the Chemical Nature of the Substance Inducing Transformation of Pneumococcal Types: Induction of Transformation by a Desoxyribonucleic Acid Fraction Isolated from Pneumococcus Type III. J. Exp. Med. 1944, 79, 137-158. [CrossRef] [PubMed]

22. Watson, J.D.; Crick, F.H. The structure of DNA. Cold Spring Harb. Symp. Quant. Biol. 1953, 18, $123-131$. [CrossRef] [PubMed]

23. Miller, E.C. Some current perspectives on chemical carcinogenesis in humans and experimental animals: Presidential Address. Cancer Res. 1978, 38, 1479-1496. [PubMed]

24. Wogan, G.N.; Hecht, S.S.; Felton, J.S.; Conney, A.H.; Loeb, L.A. Environmental and chemical carcinogenesis. Semin. Cancer Biol. 2004, 14, 473-486. [CrossRef] [PubMed]

25. Pullman, A.; Pullman, B. Electronic structure and carcinogenic activity of aromatic molecules; new developments. Adv. Cancer Res. 1955, 3, 117-169. [PubMed]

26. Harvey, R.G. Historical Overview of Chemical Carcinogenesis. Curr. Cancer Res. 2011, 6, 1-26.

27. Singer, B.; Grunberger, D. Molecular Biology of Mutagens and Carcinogens; Plenum Press: New York, NY, USA, 1983.

28. Varghese, A.J.; Wang, S.Y. Ultraviolet irradiation of DNA in vitro and in vivo produces a $3 d$ thymine-derived product. Science 1967, 156, 955-957. [CrossRef] [PubMed]

29. Wang, S.Y.; Varghese, A.J. Cytosine-thymine addition product from DNA irradiated with ultraviolet light. Biochem. Biophys. Res. Commun. 1967, 29, 543-549. [CrossRef]

30. Wang, S.Y.; Patrick, M.H.; Varghese, A.J.; Rupert, C.S. Concerning the mechanism of formation of UV-induced thymine photoproducts in DNA. Proc. Natl. Acad. Sci. USA 1967, 57, 465-472. [CrossRef] [PubMed]

31. Varghese, A.J.; Wang, S.Y. Cis-syn thymine homodimer from ultra-violet irradiated calf thymus DNA. Nature 1967, 213, 909-910. [CrossRef] [PubMed]

32. Berenblum, I.; Shuvik, P. The persistence of latent tumor cells induced in the mouse's skin by a single application of 9,10-dimethyl-1,2-benzanthracene. Br. J. Cancer 1949, 3, 384-386. [CrossRef] [PubMed]

33. Hecker, E. Phorbol esters from croton oil. Chemical nature and biological activities. Naturwissenschaften 1967, 54, 282-284. [CrossRef] [PubMed]

34. Argyris, T.S.; Slaga, T.J. Promotion of carcinomas by repeated abrasion in initiated skin of mice. Cancer Res. 1981, 41, 5193-5195. [PubMed]

35. Reiners, J.J., Jr.; Nesnow, S.; Slaga, T.J. Murine susceptibility to two-stage skin carcinogenesis is influenced by the agent used for promotion. Carcinogenesis 1984, 5, 301-307. [CrossRef] [PubMed]

36. Naito, M.; Naito, Y.; DiGiovanni, J. Comparison of the histological changes in the skin of DBA/2 and C57BL/ 6 mice following exposure to various promoting agents. Carcinogenesis 1987, 8, 1807-1815. [CrossRef] [PubMed]

37. Walborg, E.F., Jr.; DiGiovanni, J.; Conti, C.J.; Slaga, T.J.; Freeman, J.J.; Steup, D.R.; Skisak, C.M. Short-term biomarkers of tumor promotion in mouse skin treated with petroleum middle distillates. Toxicol. Sci. 1998, 45, 137-145. [PubMed]

38. McCann, J.; Choi, E.; Yamasaki, E.; Ames, B.N. Detection of carcinogens as mutagens in the Salmonella/microsome test: Assay of 300 chemicals. Proc. Natl. Acad. Sci. USA 1975, 72, 5135-5139. [CrossRef] [PubMed]

39. Cupples, C.G.; Miller, J.H. A set of lacZ mutations in Escherichia coli that allow rapid detection of each of the six base substitutions. Proc. Natl. Acad. Sci. USA 1989, 86, 5345-5349. [CrossRef] [PubMed]

40. Clive, D.; Johnson, K.O.; Spector, J.F.; Batson, A.G.; Brown, M.M. Validation and characterization of the L5178Y $/ \mathrm{TK}^{+/-}$mouse lymphoma mutagen assay system. Mutat. Res. 1979, 59, 61-108. [CrossRef] 
41. Kraemer, K.H.; Seidman, M.M. Use of supF, an Escherichia coli tyrosine suppressor tRNA gene, as a mutagenic target in shuttle-vector plasmids. Mutat. Res. 1989, 220, 61-72. [CrossRef]

42. Ohkawa, Y.; Iwata, K.; Shibuya, H.; Fujiki, H.; Inui, N. A rapid, simple screening method for skin-tumor promoters using mouse peritoneal macrophages in vitro. Cancer Lett. 1984, 21, 253-260. [CrossRef]

43. Vogelstein, B.; Fearon, E.R.; Hamilton, S.R.; Kern, S.E.; Preisinger, A.C.; Leppert, M.; Nakamura, Y.; White, R.; Smits, A.M.; Bos, J.L. Genetic alterations during colorectal-tumor development. N. Engl. J. Med. 1988, 319, 525-532. [CrossRef] [PubMed]

44. Kinzler, K.W.; Vogelstein, B. Lessons from hereditary colorectal cancer. Cell 1996, 87, 159-170. [CrossRef]

45. Rakoff-Nahoum, S. Why cancer and inflammation? Yale J. Biol. Med. 2006, 79, 123-130. [PubMed]

46. Kemp, C.J. Animal Models of Chemical Carcinogenesis: Driving Breakthroughs in Cancer Research for 100 Years. Cold Spring Harb. Protoc. 2015, 865-874. [CrossRef] [PubMed]

47. Fujiki, H.; Mori, M.; Nakayasu, M.; Terada, M.; Sugimura, T.; Moore, R.E. Indole alkaloids: Dihydroteleocidin B, teleocidin, and lyngbyatoxin A as members of a new class of tumor promoters. Proc. Natl. Acad. Sci. USA 1981, 78, 3872-3876. [CrossRef] [PubMed]

48. Fujiki, H.; Sugimura, T. New classes of tumor promoters: Teleocidin, aplysiatoxin, and palytoxin. Adv. Cancer Res. 1987, 49, 223-264. [PubMed]

49. DiGiovanni, J. Multistage carcinogenesis in mouse skin. Pharmacol. Ther. 1992, 54, 63-128. [CrossRef]

50. Castagna, M.; Takai, Y.; Kaibuchi, K.; Sano, K.; Kikkawa, U.; Nishizuka, Y. Direct activation of calcium-activated, phospholipid-dependent protein kinase by tumor-promoting phorbol esters. J. Biol. Chem. 1982, 257, 7847-7851. [PubMed]

51. Slaga, T.J.; Klein-Szanto, A.J.; Triplett, L.L.; Yotti, L.P.; Trosko, K.E. Skin tumor-promoting activity of benzoyl peroxide, a widely used free radical-generating compound. Science 1981, 213, 1023-1025. [CrossRef] [PubMed]

52. Fujiki, H.; Sueoka, E.; Suganuma, M. Tumor promoters: From chemicals to inflammatory proteins. J. Cancer Res. Clin. Oncol. 2013, 139, 1603-1614. [CrossRef] [PubMed]

53. Lindahl, T. Suppression of spontaneous mutagenesis in human cells by DNA base excision-repair. Mutat. Res. 2000, 462, 129-135. [CrossRef]

54. Friedberg, E.C.; Aguilera, A.; Gellert, M.; Hanawalt, P.C.; Hays, J.B.; Lehmann, A.R.; Lindahl, T.; Lowndes, N.; Sarasin, A.; Wood, R.D. DNA repair: From molecular mechanism to human disease. DNA Repair (Amst.) 2006, 5, 986-996. [CrossRef] [PubMed]

55. Arczewska, K.D.; Michalickova, K.; Donaldson, I.M.; Nilsen, H. The contribution of DNA base damage to human cancer is modulated by the base excision repair interaction network. Crit. Rev. Oncog. 2008, 14, 217-273. [CrossRef] [PubMed]

56. Spivak, G. Nucleotide excision repair in humans. DNA Repair (Amst.) 2015, 36, 13-18. [CrossRef] [PubMed]

57. Modrich, P. Mechanisms in E. coli and Human Mismatch Repair (Nobel Lecture). Angew. Chem. Int. Ed. Engl. 2016, 55, 8490-8501. [CrossRef] [PubMed]

58. Kastan, M.B.; Bartek, J. Cell-cycle checkpoints and cancer. Nature 2004, 432, 316-323. [CrossRef] [PubMed]

59. Basu, A.K.; Essigmann, J.M. Site-specifically alkylated oligodeoxynucleotides: Probes for mutagenesis, DNA repair and the structural effects of DNA damage. Mutat. Res. 1990, 233, 189-201. [CrossRef]

60. Otteneder, M.; Lutz, W.K. Correlation of DNA adduct levels with tumor incidence: Carcinogenic potency of DNA adducts. Mutat. Res. 1999, 424, 237-247. [CrossRef]

61. Basu, A.K. Mutagenesis: The Outcome of Faulty Replication of DNA. In Chemical Carcinogenesis; Penning, T.M., Ed.; Humana Press: New York, NY, USA, 2011; pp. 375-399.

62. Burgers, P.M.; Koonin, E.V.; Bruford, E.; Blanco, L.; Burtis, K.C.; Christman, M.F.; Copeland, W.C.; Friedberg, E.C.; Hanaoka, F.; Hinkle, D.C.; et al. Eukaryotic DNA polymerases: Proposal for a revised nomenclature. J. Biol. Chem. 2001, 276, 43487-43490. [CrossRef] [PubMed]

63. Ohmori, H.; Friedberg, E.C.; Fuchs, R.P.; Goodman, M.F.; Hanaoka, F.; Hinkle, D.; Kunkel, T.A.; Lawrence, C.W.; Livneh, Z.; Nohmi, T.; et al. The Y-family of DNA polymerases. Mol. Cell 2001, 8, 7-8. [CrossRef]

64. Burgers, P.M.; Gordenin, D.; Kunkel, T.A. Who Is Leading the Replication Fork, Pol epsilon or Pol delta? Mol. Cell 2016, 61, 492-493. [CrossRef] [PubMed]

65. Johnson, R.E.; Klassen, R.; Prakash, L.; Prakash, S. Response to Burgers et al. Mol. Cell 2016, 61, 494-495. [CrossRef] [PubMed] 
66. Johnson, R.E.; Klassen, R.; Prakash, L.; Prakash, S. A Major Role of DNA Polymerase delta in Replication of Both the Leading and Lagging DNA Strands. Mol. Cell 2015, 59, 163-175. [CrossRef] [PubMed]

67. Phillips, A.J. The epidemiology of cancer. Can. Fam. Physician 1969, 15, 44-47. [PubMed]

68. Levin, M.L.; Goldstein, H.; Gerhardt, P.R. Cancer and tobacco smoking: A preliminary report. J. Am. Med. Assoc. 1950, 143, 336-338. [CrossRef] [PubMed]

69. Doll, R. On the etiology of lung cancer. J. Natl. Cancer Inst. 1950, 11, 638-640. [PubMed]

70. Doll, R.; Hill, A.B. Smoking and carcinoma of the lung; preliminary report. Br. Med. J. 1950, 2, 739-748. [CrossRef] [PubMed]

71. Willett, W.C. Diet and cancer: One view at the start of the millennium. Cancer Epidemiol. Biomark. Prev. 2001, 10,3-8.

72. Willett, W.C. Diet and breast cancer. J. Intern. Med. 2001, 249, 395-411. [CrossRef] [PubMed]

73. Verhoeven, D.T.; Goldbohm, R.A.; van Poppel, G.; Verhagen, H.; van den Brandt, P.A. Epidemiological studies on brassica vegetables and cancer risk. Cancer Epidemiol. Biomark. Prev. 1996, 5, 733-748.

74. Surgeon General. Reducing the Health Consequences of Smoking: 25 Years of Progress; U.S. Government Publishing Office: Washington, DC, USA, 1989.

75. Hecht, S.S.; Carmella, S.G.; Chen, M.; Dor Koch, J.F.; Miller, A.T.; Murphy, S.E.; Jensen, J.A.; Zimmerman, C.L.; Hatsukami, D.K. Quantitation of urinary metabolites of a tobacco-specific lung carcinogen after smoking cessation. Cancer Res. 1999, 59, 590-596. [PubMed]

76. Mercincavage, M.; Souprountchouk, V.; Tang, K.Z.; Dumont, R.L.; Wileyto, E.P.; Carmella, S.G.; Hecht, S.S.; Strasser, A.A. A Randomized Controlled Trial of Progressively Reduced Nicotine Content Cigarettes on Smoking Behaviors, Biomarkers of Exposure, and Subjective Ratings. Cancer Epidemiol. Biomark. Prev. 2016, 25, 1125-1133. [CrossRef] [PubMed]

77. Chen, L.H.; Quinn, V.; Xu, L.; Gould, M.K.; Jacobsen, S.J.; Koebnick, C.; Reynolds, K.; Hechter, R.C.; Chao, C.R. The accuracy and trends of smoking history documentation in electronic medical records in a large managed care organization. Subst. Use Misuse 2013, 48, 731-742. [CrossRef] [PubMed]

78. Diepgen, T.L.; Mahler, V. The epidemiology of skin cancer. Br. J. Dermatol. 2002, 146 (Suppl. 61), 1-6. [CrossRef] [PubMed]

79. Greenman, C.; Stephens, P.; Smith, R.; Dalgliesh, G.L.; Hunter, C.; Bignell, G.; Davies, H.; Teague, J.; Butler, A.; Stevens, C.; et al. Patterns of somatic mutation in human cancer genomes. Nature 2007, 446, 153-158. [CrossRef] [PubMed]

80. Lea, I.A.; Jackson, M.A.; Li, X.; Bailey, S.; Peddada, S.D.; Dunnick, J.K. Genetic pathways and mutation profiles of human cancers: Site- and exposure-specific patterns. Carcinogenesis 2007, 28, 1851-1858. [CrossRef] [PubMed]

81. Boveri, T. Concerning the origin of malignant tumours by Theodor Boveri. Translated and annotated by Henry Harris. J. Cell Sci. 2008, 121 (Suppl. 1), 1-84. [CrossRef] [PubMed]

82. Nordling, C.O. A new theory on cancer-inducing mechanism. Br. J. Cancer 1953, 7, 68-72. [CrossRef] [PubMed]

83. Ashley, D.J. The two "hit" and multiple "hit" theories of carcinogenesis. Br. J. Cancer 1969, 23, 313-328. [CrossRef] [PubMed]

84. Knudson, A.G. Hereditary cancer: Two hits revisited. J. Cancer Res. Clin. Oncol. 1996, 122, 135-140. [CrossRef] [PubMed]

85. Fearon, E.R.; Vogelstein, B. A genetic model for colorectal tumorigenesis. Cell 1990, 61, 759-767. [CrossRef]

86. Bignell, G.R.; Santarius, T.; Pole, J.C.; Butler, A.P.; Perry, J.; Pleasance, E.; Greenman, C.; Menzies, A.; Taylor, S.; Edkins, S.; et al. Architectures of somatic genomic rearrangement in human cancer amplicons at sequence-level resolution. Genome Res. 2007, 17, 1296-1303. [CrossRef] [PubMed]

87. Brucher, B.L.; Jamall, I.S. Somatic Mutation Theory-Why it's Wrong for Most Cancers. Cell. Physiol. Biochem. 2016, 38, 1663-1680. [CrossRef] [PubMed]

88. Shen, H.M.; Ong, C.N. Mutations of the $p 53$ tumor suppressor gene and ras oncogenes in aflatoxin hepatocarcinogenesis. Mutat. Res. 1996, 366, 23-44. [CrossRef]

89. Ronai, Z.A.; Gradia, S.; Peterson, L.A.; Hecht, S.S. G to A transitions and G to T transversions in codon 12 of the $\mathrm{Ki}$-ras oncogene isolated from mouse lung tumors induced by 4-(methylnitrosamino)-1-(3-pyridyl)-1-butanone (NNK) and related DNA methylating and pyridyloxobutylating agents. Carcinogenesis 1993, 14, 2419-2422. [CrossRef] [PubMed] 
90. Greenblatt, M.S.; Bennett, W.P.; Hollstein, M.; Harris, C.C. Mutations in the $p 53$ tumor suppressor gene: Clues to cancer etiology and molecular pathogenesis. Cancer Res. 1994, 54, 4855-4878. [PubMed]

91. Aguilar, F.; Hussain, S.P.; Cerutti, P. Aflatoxin $B_{1}$ induces the transversion of G->T in codon 249 of the $p 53$ tumor suppressor gene in human hepatocytes. Proc. Natl. Acad. Sci. USA 1993, 90, 8586-8590. [CrossRef] [PubMed]

92. Hainaut, P.; Soussi, T.; Shomer, B.; Hollstein, M.; Greenblatt, M.; Hovig, E.; Harris, C.C.; Montesano, R. Database of $p 53$ gene somatic mutations in human tumors and cell lines: Updated compilation and future prospects. Nucleic Acids Res. 1997, 25, 151-157. [CrossRef] [PubMed]

93. Pfeifer, G.P.; Hainaut, P. On the origin of G-> T transversions in lung cancer. Mutat. Res. 2003, 526, 39-43. [CrossRef]

94. Harris, C.C.; Hirohashi, S.; Ito, N.; Pitot, H.C.; Sugimura, T.; Terada, M.; Yokota, J. Multistage carcinogenesis: The Twenty-Second International Symposium of the Princess Takamatsu Cancer Research Fund. Cancer Res. 1992, 52, 4837-4840. [PubMed]

95. Harris, C.C. Tumour suppressor genes, multistage carcinogenesis and molecular epidemiology. IARC Sci. Publ. 1992, 67-85.

96. Loeb, L.A.; Springgate, C.F.; Battula, N. Errors in DNA replication as a basis of malignant changes. Cancer Res. 1974, 34, 2311-2321. [PubMed]

97. Beckman, R.A.; Loeb, L.A. Efficiency of carcinogenesis with and without a mutator mutation. Proc. Natl. Acad. Sci. USA 2006, 103, 14140-14145. [CrossRef] [PubMed]

98. Branch, P.; Hampson, R.; Karran, P. DNA mismatch binding defects, DNA damage tolerance, and mutator phenotypes in human colorectal carcinoma cell lines. Cancer Res. 1995, 55, 2304-2309. [PubMed]

99. Strickler, J.G.; Zheng, J.; Shu, Q.; Burgart, L.J.; Alberts, S.R.; Shibata, D. p53 mutations and microsatellite instability in sporadic gastric cancer: When guardians fail. Cancer Res. 1994, 54, 4750-4755. [PubMed]

100. Tomlinson, I.P.; Novelli, M.R.; Bodmer, W.F. The mutation rate and cancer. Proc. Natl. Acad. Sci. USA 1996, 93, 14800-14803. [CrossRef] [PubMed]

101. Hanahan, D.; Weinberg, R.A. The hallmarks of cancer. Cell 2000, 100, 57-70. [CrossRef]

102. Lazebnik, Y. What are the hallmarks of cancer? Nat. Rev. Cancer 2010, 10, 232-233. [CrossRef] [PubMed]

103. Hanahan, D.; Weinberg, R.A. Hallmarks of cancer: The next generation. Cell 2011, 144, 646-674. [CrossRef] [PubMed]

104. Sonnenschein, C.; Soto, A.M. The aging of the 2000 and 2011 Hallmarks of Cancer reviews: A critique. J. Biosci. 2013, 38, 651-663. [CrossRef] [PubMed]

105. Siegel, R.L.; Miller, K.D.; Jemal, A. Cancer statistics, 2016. CA Cancer J. Clin. 2016, 66, 7-30. [CrossRef] [PubMed]

106. Chen, W.; Zheng, R.; Baade, P.D.; Zhang, S.; Zeng, H.; Bray, F.; Jemal, A.; Yu, X.Q.; He, J. Cancer statistics in China, 2015. CA Cancer J. Clin. 2016, 66, 115-132. [CrossRef] [PubMed]

107. Jemal, A.; Bray, F.; Center, M.M.; Ferlay, J.; Ward, E.; Forman, D. Global cancer statistics. CA Cancer J. Clin. 2011, 61, 69-90. [CrossRef] [PubMed]

(C) 2018 by the author. Licensee MDPI, Basel, Switzerland. This article is an open access article distributed under the terms and conditions of the Creative Commons Attribution (CC BY) license (http://creativecommons.org/licenses/by/4.0/). 